\title{
Effect of Papaya Juice and Gelatine on the Physicochemical and Acceptability of Yoghurt
}

\author{
Tilahun Tefera ${ }^{1}$, Negussie F Bussa ${ }^{2 *}$, Solomon Abera ${ }^{2}$ and Geremew Bultosa ${ }^{2}$ \\ ${ }^{1}$ Fedis Agricultural Research Center, Ethiopia \\ ${ }^{2}$ Haramaya University, Ethiopia
}

*Corresponding author: Negussie F Bussa, Haramaya University, Institute of Technology, School of Food science, Ethiopia.

Received Date: February 18, 2019

Published Date: March 20, 2019

\begin{abstract}
Yoghurt contains beneficial bacteria that confer health benefits to the consumer. Yoghurt combined with papaya juice may result in a product with enhanced functional and nutritional properties, and sensory acceptability. Papaya possesses antioxidant properties as it is rich in $\beta$-carotene and phenolic compounds. The objective of this research was to investigate the effect of papaya juice supplementation and levels of gelatin addition on physicochemical and acceptability of yoghurt. The experiment was laid out in a $3 \times 4$ full factorial arrangement where each of three gelatin addition levels $(0.5,0.6$ and $0.7 \% \mathrm{w} / \mathrm{v}$ of the milk) were combined with one of the four papaya juice addition levels $(0,10,15$ and $20 \% \mathrm{w} / \mathrm{w}$ of the base milk) to give twelve different yoghurt formulations. Proximate composition, total phenolics, total carotenoids and reducing power of yoghurt samples were determined on day 1 whereas yoghurt firmness and consumer acceptance tests were done on day 7. The addition of papaya juice to yoghurt formula resulted in a decrease in fat and an increase in the total solids, protein and ash values. The addition of gelatin improved the syneresis and firmness of yoghurt. Increased amount of gelatin and papaya juice addition significantly $(\mathrm{P} \leq 0.05)$ decreased the syneresis of yoghurt samples and increased the firmness. The total carotene, phenolic and reducing power of yoghurt samples were significantly $(\mathrm{P} \leq 0.05)$ increased with the increased papaya juice level. Panelists favored samples with $10 \%$ papaya juice and $0.5 \%$ gelatin in terms of appearance, color and overall acceptability. The results indicated the viability of commercially producing papaya juice supplemented yoghurt along with gelatin to combat syneresis, improve firmness, enhanced the total carotenoids, phenol and reducing power, crude protein and total solid of the yoghurt samples. Therefore, it is concluded that addition of papaya juice into yogurt improves the nutritional and functional property of yoghurt.
\end{abstract}

Keywords: Yoghurt; Nutrition; Gelatin; Papaya juice; Syneresis

\section{Introduction}

In Ethiopia, a significant proportion of milk is consumed in the form of Ergo were the fermentation process is usually natural $[1,2]$. Yoghurt production is a well-controlled process that utilizes pure cultures of lactic acid bacteria, which are responsible for the fermentation process.

Yoghurt is a healthy and delicious food due to its high nutritive and therapeutic value [3]. Generally considered as a safer product and well known and most popular worldwide [4,5].

The associations of fruits with cultured dairy products have created healthy perceptions in the consumers mind. Papaya fruit provides health benefits because it is sources of vitamins, minerals, antioxidants and dietary fibers [6].
It has nutritional, medicinal, and pharmacological and a therapeutic effect on the human body [7]. Milk is rich in protein and fat, but it is deficient in vitamins and fiber. Thus, blending milk with papaya juice for yoghurt would produce a nutritionally rich functional food.

Gelatin enhances the viscosity, influence texture, creaminess and mouth feel as well as prevents separation of whey from yoghurt [8]. Considering the above, the production of a functional yoghurt with papaya juice. Is an alternative for the increasing market of health-conscious consumers and may contribute to an increase in the vitamins and mineral consumption? The objectives of the present work were to develop cow's milk yoghurt added with 
papaya juice and gelatin and to study the physical and nutritional properties as a function of the levels of papaya juice and gelatine.

\section{Materials and Methods}

The experiment was conducted in the laboratory of the Food Science, and Dairy laboratory, Haramaya University. Fresh whole cow's milk was collected from Haramaya University dairy farm. Fresh papaya was purchased directly from a farmer's field. The milk and papaya juice were analyzed for proximate compositions. Gelatin with 240 Blooms manufactured in Brazil by Bake Mate) was purchased from supermarket, Addis Ababa, Ethiopia. Freeze-dried yoghurt starter culture (YC-X11 CHR HANSEN), was purchased from chemical supplier, Yomex- import and export, Addis Ababa, Ethiopia.

\section{Yoghurt production}

Prior to yoghurt preparation all equipment used for yoghurt manufacturing were sterilized in autoclave after thoroughly washing them. A freeze-dried yoghurt starter culture was used to inoculate fresh milk 1lt, which had been heated at $90{ }^{\circ} \mathrm{C}$ for $30 \mathrm{~min}$. and immediately cold to $45{ }^{\circ} \mathrm{C}$. The inoculated milk was incubated at $43{ }^{\circ} \mathrm{C}$ until pH 4.6 was attained, then stored overnight at $4{ }^{\circ} \mathrm{C}$ and then used in the yoghurt preparation. Three different blends of gelatin at a level of $0.5,0.6$ and $0.7 \%$ with sugar at $4 \%$ milk base were prepared. The fresh milk $3 \times 4 \mathrm{~L}$ was preheated to $50{ }^{\circ} \mathrm{C}$ to facilitate melting of gelatin and uniform mixing of ingredients.

The mixes were pasteurized at $90{ }^{\circ} \mathrm{C}$ for 30 minutes and the three premixes each was further divided into four equal portions and in each portion papaya juice (at a level of $0,10,15$ and $20 \%$ (w/v) was added and then rapidly cooled to $45^{\circ} \mathrm{C}$. The inoculated milk was added at the rate of $0.03 \%$ served as starter culture into each mix. The resulting 12 different yoghurt formulations were further divided into three each coded screw capped glass jars and a temperature of $43{ }^{\circ} \mathrm{C}$ was maintained throughout the incubation period until the $\mathrm{pH}$ of the control yoghurt reached 4.7 .

The yoghurt samples were transferring to a refrigerator at $4{ }^{\circ} \mathrm{C}$ and then taken out and left at room temperature prior to analyses. The samples were then homogenized to obtain a uniform mixture for further analysis. Physico-chemical, total phenolics and carotenoids of yoghurt samples were determined on day1 whereas yoghurt firmness and consumer acceptance tests were done on day 7.

\section{Physicochemical analysis}

The papaya juice, fresh milk and yoghurt samples were analysed for moisture by oven- drying method crude fat using the Mojonnier method, crude protein using Kjeldahl method and ash by furnace-drying [9]. The total soluble solid content was determined with a refractometer (Hanna H1 96801, USA). The carbohydrate and calorie values were obtained by calculation.

A firmness analysis was performed with a texture analyser, TAXT2 model using an Expert Software version 1.05 (Stable Micro Systems, Surrey, UK). The analytical method was modified from
[10]. An aluminium cylinder probe P36R with a diameter of $35 \mathrm{~mm}$ was used. A compression strain of $60 \%$ was used with a $5 \mathrm{~kg}$ load cell at a speed of $5 \mathrm{mms}^{-1}$. The firmness of the yoghurt samples was measured in triplicates.

Syneresis of the homogenised yoghurt was determined by placing the no. 1 Whatman filter paper in a Buchner funnel. The funnel was then placed in an Erlenmeyer flask and attached to a vacuum pump (Fisher Scientific, FB 70155). A total of $20 \mathrm{~g}$ of each yoghurt samples was then spread evenly on the filter paper and vacuum-filtered for $10 \mathrm{~min}$. The collected residue was weighed and percent syneresis was calculated by dividing the weight of the residue by the initial sample weight multiplied by 100 [11].

\section{Total phenolic, carotenoids and reducing power}

The total phenolic content of the papaya juice and yoghurt samples was determined using the DCPIP titrimetric method [9]. The standard used was a solution of $100 \mathrm{mg}$ gallic acid diluted with 3\% HPO3: HOAC to $100 \mathrm{ml}$ in a volumetric flask. The dye solution was prepared by dissolving $50 \mathrm{mg} \mathrm{2,6-dichloroindophenol} \mathrm{in} \mathrm{hot}$ water containing $42 \mathrm{mg}$ sodium carbonate. A total of $10 \mathrm{~g}$ each of the sample was then added to 3\% HPO3: HOAC and filtered with no. 42 Whatman filter paper. The sample extract was titrated against the dye solution to a pink colour endpoint lasting for $15 \mathrm{sec}$. The extract obtained was used for Spectrophotometric analysis of total phenolics and reducing power. All of the analyses were run in triplicate.

Total carotenoids content of papaya juice and yoghurt samples was determined according [12-15]. Papaya juice sample (1g) and yoghurt samples $(5 \mathrm{~g})$ were mixed with $37.5 \mathrm{ml}$ methanol and $12.5 \mathrm{ml}$ of $50 \%$ Potassium hydroxide solution in a flask for saponification. Then unsaponifiable materials were extracted twice with Diethyl ether (20 ml each time) and the ether extract was washed twice with distilled water ( $40 \mathrm{ml}$ each time). Next, the extract was dried over anhydrous sodium sulfate. The diethyl ether was evaporated on steam bath and the dried residue was then redissolved in petroleum ether $(20 \mathrm{ml})$. The yellow to orange color of the petroleum ether was measured at wavelength of $450 \mathrm{~nm}$ with a Spectrophotometer. The Total Carotenoids content of samples were computed using the formula shown below and the result was reported in mg equivalent of $\beta$ - carotene per $\mathrm{kg}$ of papaya juice.

$$
\text { Total carotenoid }\left(\frac{m g}{k g}\right)=\frac{A b s}{259.2} \times \frac{20 m l}{\text { sampleweight }(\mathrm{kg})}
$$

Where: Abs= absorbance reading, 259.2=extraction coefficient of $\beta$-carotene in petroleum ether

$20 \mathrm{ml}=$ volume of petroleum ether used to dissolve carotenoids extract.

\section{Sensory evaluation}

Twenty-five panellists (13 males and 12 females from Haramaya University) were purposely selected for sensory evaluation. A hedonic form with a 9-point scale was given to each panel. The 
yoghurt samples were served in randomised order in small cups coded with three random digits. The hedonic form scales ranged from 1, representing 'dislike very much', to 9, representing 'like very much'. The sensory parameters used were color, appearance, body and texture, flavor and over all acceptability.

\section{Statistical analysis}

All data were analysed using SPSS version 17.0 for Windows (SPSS Inc., Chicago, IL, USA) with a one-way analysis of variance (ANOVA). A Duncan's multiple range tests was used to analyse the differences between the individual means at a 5\% significance level.

\section{Results and Discussions}

\section{Chemical analysis of milk and papaya juice}

Quality of Milk and papaya used for yoghurt production was analysed before use. Moisture, total solid, fat, protein, ash, acidity, $\mathrm{pH}$, and solid-non-fat (SNF) were determined. Results of chemical analysis of milk and papaya are shown in (Table $1 \& 2$ ). The results were more or less similar to earlier studies, [16-18], respectively.

Table 1: Proximate Composition of milk used for yoghurt production.

\begin{tabular}{|l|c|}
\hline \multicolumn{1}{|c|}{ Parameter } & Mean \pm SD \\
\hline Total Solids $(\% \mathrm{w} / \mathrm{w})$ & $11.56 \pm 0.01$ \\
\hline Moisture $(\% \mathrm{w} / \mathrm{w})$ & $88.45 \pm 0.05$ \\
\hline Solid-not-fat $(\% \mathrm{w} / \mathrm{w})$ & $8.06 \pm 0.01$ \\
\hline Protein $(\% \mathrm{w} / \mathrm{w})$ & $3.05 \pm 0.03$ \\
\hline Fat $(\% \mathrm{w} / \mathrm{w})$ & $3.61 \pm 0.15$ \\
\hline Ash $(\% \mathrm{w} / \mathrm{w})$ & $0.71 \pm 0.04$ \\
\hline Titratable acidity $(\% \mathrm{w} / \mathrm{w}$ lactic acid) & $0.13 \pm 0.01$ \\
\hline pH & $6.62 \pm 0.05$ \\
\hline
\end{tabular}

Values are means \pm standard deviation of triplicate sample, expressed on fresh milk weight basis.

Table 2: Proximate composition of papaya juice used for yoghurt production.

\begin{tabular}{|c|c|}
\hline Parameters & Mean \pm SD \\
\hline Total solid (\% w/w) & $19.60 \pm 0.12$ \\
\hline Moisture (\% w/w) & $80.40 \pm 0.07$ \\
\hline Total soluble solids ( $\left.{ }^{0} \mathrm{Brix}\right)$ & $8.80 \pm 0.20$ \\
\hline crude protein $(\% \mathrm{w} / \mathrm{w})$ & $6.20 \pm 0.15$ \\
\hline Total carotenoids (mg/Kg) & $68.25 \pm 10.9$ \\
\hline Total sugar (\% w/w) & $7.38 \pm 1.66$ \\
\hline Total phenols (mg GAE/Kg) & $53.70 \pm 3.20$ \\
\hline Reducing Power (mg AAE/Kg) & $541.60 \pm 0.99$ \\
\hline Titratable acidity (as citric acid \% w/w) & $0.23 \pm 0.02$ \\
\hline $\mathrm{pH}$ & $4.50 \pm 0.10$ \\
\hline
\end{tabular}

Values are mean \pm standard deviation of triplicate samples, expressed on $100 \mathrm{~g}$ of fresh juice in weight basis.

\section{Physical and nutritional properties of papaya yoghurt}

The results of the proximate composition, Total phenolics, Total carotenoids, reducing power, Texture analysis (yoghurt firmness) and syneresis of the yoghurt samples are presented and discussed in the subsequent sections.

\section{Proximate composition of yoghurt}

Total solids content, moisture content, crude protein, fat, ash and solids-not-fat of yoghurt samples were ranged from $16.29 \pm 0.06$ to $16.85 \pm 0.19 \%, 83.04 \pm 0.05$ to $83.79 \pm 0.09, \quad 3.02 \pm 0.01$ to $3.24 \pm 0.08,2.86 \pm 0.09$ to $3.16 \pm 0.09 \%$, and $0.71 \pm 0.01$ to $0.74 \pm 0.01 \%$ and $13.04 \pm 0.29$ to $13.96 \pm 0.09 \%$, respectively (Table 3 ). The total solids, protein, solid-not-fat, and ash contents of papaya added yoghurt were higher than in control (without papaya) yoghurt. The fat content of papaya added yoghurts decreased compared with control yoghurts. The maximum protein content was recorded in the yoghurt samples with papaya juice and gelatine. Papaya was rich in protein and these papaya fibres increased protein contents in yogurt in high ratio (Table 2).

The ash content of the control (yoghurt without papaya juice) was lower than that of the papaya supplemented yoghurt (Table 3). The ash content is the amount of non-combustible matter and total minerals present in a food. Therefore, addition of the papaya juice to the milk had increased the ash and thus the mineral contents of the papaya - yoghurt than in the control (Table 3).

Table 3: Proximate composition of yoghurt produced using various papaya juice levels.

\begin{tabular}{|c|c|c|c|c|}
\hline \multirow{2}{*}{ Parameters } & \multicolumn{4}{|c|}{ Papaya Juice (\%, w/w) } \\
\cline { 2 - 5 } & $\mathbf{0}$ & 10 & 15 & $\mathbf{1 0}$ \\
\hline $\begin{array}{c}\text { Total solids } \\
(\%)\end{array}$ & $16.29 \pm 0.06^{\mathrm{d}}$ & $16.52 \pm 0.19^{\mathrm{c}}$ & $16.81 \pm 0.19^{\mathrm{b}}$ & $16.85 \pm 0.19^{\mathrm{a}}$ \\
\hline $\begin{array}{c}\text { Moisture } \\
\text { content (\%) }\end{array}$ & $83.79 \pm 0.09^{\mathrm{a}}$ & $83.47 \pm 0.19^{\mathrm{ab}}$ & $83.18 \pm 0.18^{\mathrm{c}}$ & $83.04 \pm 0.05^{\mathrm{d}}$ \\
\hline $\begin{array}{c}\text { Crude pro- } \\
\text { tein (\%) }\end{array}$ & $3.02 \pm 0.01^{\mathrm{c}}$ & $3.07 \pm 0.09^{\mathrm{c}}$ & $3.13 \pm 0.09^{\mathrm{b}}$ & $3.24 \pm 0.08^{\mathrm{a}}$ \\
\hline Fat (\%) & $3.16 \pm 0.09^{\mathrm{a}}$ & $3.08 \pm 0.19^{\mathrm{b}}$ & $2.92 \pm 0.09^{\mathrm{c}}$ & $2.86 \pm 0.09^{\mathrm{d}}$ \\
\hline $\begin{array}{c}\text { Solid-not-fat } \\
(\%)\end{array}$ & $13.04 \pm 0.29^{\mathrm{d}}$ & $13.44 \pm 0.28^{\mathrm{c}}$ & $13.75 \pm 0.19^{\mathrm{b}}$ & $13.96 \pm 0.0^{\mathrm{a}}$ \\
\hline Ash (\%) & $0.71 \pm 0.01^{\mathrm{c}}$ & $0.72 \pm 0.01^{\mathrm{bc}}$ & $0.73 \pm 0.01^{\mathrm{b}}$ & $0.74 \pm 0.01^{\mathrm{a}}$ \\
\hline
\end{tabular}

Different superscripted letters in each row indicates significant difference between the samples at a level of $(P<0.05)$. The values given were on weight basis $(\%, w / w)$. Values were given as average \pm standard deviation.

The variation in the proximate composition of yoghurt samples was due to the compositional difference between papaya juice and the base milk used (Table 1 and 2). Generally, the addition of papaya juice had a concentration effect on the composition of yoghurt, and this was due to higher total solid (TS) content of papaya juice as compared to milk. According to the draft COMESA/ East African standard, yoghurt should have a minimum total solidnot- fat content of $8.2 \%(\mathrm{w} / \mathrm{w})$. Codex stated yoghurt should have a minimum of $2.7 \%$ protein and a fat content of less than $15 \%$. Similarly, in this study, all yoghurt samples satisfied the above requirements (Table 3 ).

\section{Total carotenoids, total phenolics and reducing power}

The TC, TP and RP content of plain yoghurt samples observed in this study were almost similar with findings of [17], and little higher than the findings of [4] who reported TP content of 2.025 
mg GAE/100 g in the plain yoghurt samples. This could probably be due to differences in phenol content of milk samples used in the experiments. The occurrence of TC, TP and consequently RP in milk and dairy products may be consequence of several factors, e.g., the consumption of particular fodder crops by cattle, the catabolism of proteins by bacteria, contamination with sanitizing agents, process- induced incorporation or their deliberate addition as specific flavouring or functional ingredients [19].

The TC and TP content of papaya in the literature is quite variable, which could be due to differences in cultivar [20] preharvest management [21], post-harvest handling and storage [22], processing method and the methods of analysis $[19,23]$. The TP content of the papaya juice used in this study was higher than the value (28mg GAE/100g) reported [29-32] and lower than the result reported [33] which was $54 \mathrm{mg}$ GAE/100g of juice. The content of carotene was within the range from $8.66 \mathrm{mg} / \mathrm{Kg}$ to $78.07 \mathrm{mg} / \mathrm{Kg}$ reported [34].

In general addition of papaya juice results in increased TC, TP, and RP of yoghurt and consequently the functional food property of yoghurt was improved due to increased carotenoids and phenolic contents which in turn could act as antioxidant and provitamin A. Vitamin A malnutrition is one of the three most important nutritional problems (i.e., iron, iodine and vitamin A) in the developing countries [35] (Table 4).

Table 4: Total carotenoids (mg/100g), total phenolics (mg GAE/100g) and reducing power (mg/100gAAE) of yoghurt samples.

\begin{tabular}{|c|c|c|c|c|c|}
\hline \multirow{2}{*}{ Parameters } & \multirow[b]{2}{*}{ Gl } & \multicolumn{4}{|c|}{ Papaya Juice Level (\%, w/w) } \\
\hline & & 0 & 10 & 15 & 20 \\
\hline \multirow{3}{*}{ Total carotenoids } & 0.5 & $0.306 \pm 0.008^{\mathrm{d}}$ & $0.765 \pm 0.009^{c}$ & $0.981 \pm 0.019^{b}$ & $1.22 \pm 0.07^{\mathrm{a}}$ \\
\hline & 0.6 & $0.307 \pm 0.008^{d}$ & $0.762 \pm 0.009^{c}$ & $0.990 \pm 0.009^{b}$ & $1.22 \pm 0.01^{\mathrm{a}}$ \\
\hline & 0.7 & $0.302 \pm 0.009^{d}$ & $0.756 \pm 0.009^{c}$ & $0.985 \pm 0.009^{b}$ & $1.22 \pm 0.01^{\mathrm{a}}$ \\
\hline \multirow{3}{*}{ Total phenolics } & 0.5 & $3.57 \pm 0.03^{f}$ & $5.71 \pm 0.06^{\mathrm{e}}$ & $7.67 \pm 0.01^{c}$ & $8.77 \pm 0.01^{b}$ \\
\hline & 0.6 & $3.56 \pm 0.01^{\mathrm{f}}$ & $6.02 \pm 0.60^{\mathrm{e}}$ & $8.32 \pm 0.58^{b}$ & $9.41 \pm 0.57^{\mathrm{a}}$ \\
\hline & 0.7 & $3.67 \pm 0.08^{\mathrm{f}}$ & $6.77 \pm 0.01^{\mathrm{d}}$ & $8.78 \pm 0.01^{b}$ & $9.74 \pm 0.04^{\mathrm{a}}$ \\
\hline \multirow{2}{*}{ Reducing power } & 0.5 & $11.13 \pm 0.32^{\mathrm{c}}$ & $11.90 \pm 0.10^{\mathrm{b}}$ & $12.00 \pm 0.18^{\mathrm{ab}}$ & $12.33 \pm 0.58^{\mathrm{ab}}$ \\
\hline & 0.6 & $10.87 \pm 0.13^{c}$ & $11.93 \pm 0.08^{\mathrm{ab}}$ & $12.15 \pm 0.30^{\mathrm{ab}}$ & $12.50 \pm 0.50^{\mathrm{ab}}$ \\
\hline
\end{tabular}

$\mathrm{GI}=$ Gelatin level; $\mathrm{AAE}=$ Ascorbic Acid Equivalent; GAE=Gallic Acid Equivalent; Different superscripted letters in each column or row for the same parameter indicates significant difference between the samples at a level of $(P<0.05)$. Values were given as average \pm standard deviation.

\section{Firmness and syneresis analysis}

Significant differences $(\mathrm{p}<0.05)$ were found in firmness (Table 5 ) and syneresis (Table 6). The values for firmness were highest for the highest level of papaya juice and gelatine and lowest for the control yoghurt samples. The papaya yoghurt was significantly lower syneresis and more firmness than the control. The papaya juice had the most influence on the textural quality of the yoghurt. This result could be due to the pectin component of the papaya juice reinforcing gelatine, which tended to produce resistance to the structural deformation of the yoghurt. It was speculated that the addition of the fruit juices to the yoghurt might increase syneresis and affect the strength of the internal bonds formed in the food. The ability of a gel to exhibit syneresis, viscosity, rigidity and elasticity will be affected by the types of protein, the temperature and time of heating, the protein concentration, and the ionic strength [36]. Several studies of milk gel interaction and its rheological properties have previously been reported and noted that various polysaccharides such as xanthan gum, wheat starch, gelatine and locust bean gum can be used in yoghurt for higher shear consistency and viscosity [37-40]. The combination of pectin and sugar in the presence of acid contributed to the gelling properties of milk and subsequently affected its texture [41]. An appropriate thermal process was applied during the sample preparation to denature the enzymes papain found in papaya juice to avoid the hydrolytic digestion of milk protein. Proteolytic enzymes would have interfered with the interaction between milk casein and whey protein to form the milk-clotting structure [42].

Table 5: Firmness of the yogurt samples (Newton) (mean \pm SD).

\begin{tabular}{|c|c|c|c|}
\hline $\begin{array}{c}\text { Papaya Juice } \\
(\% \mathbf{w} / \mathbf{w})\end{array}$ & $\mathbf{3 . 5}$ & $\mathbf{0 . 6}$ & $\mathbf{0 . 7}$ \\
\hline 0 & $0.303 \pm 0.015^{\mathrm{g}}$ & $0.373 \pm 0.021^{\mathrm{ef}}$ & $0.430 \pm 0.026^{\mathrm{c}}$ \\
\hline 10 & $0.353 \pm 0.006^{\mathrm{f}}$ & $0.377 \pm 0.012^{\mathrm{ef}}$ & $0.463 \pm 0.015^{\mathrm{bc}}$ \\
\hline 15 & $0.360 \pm 0.017^{\mathrm{f}}$ & $0.403 \pm 0.006^{\mathrm{de}}$ & $0.483 \pm 0.021^{\mathrm{b}}$ \\
\hline 20 & $0.383 \pm 0.006^{\mathrm{ef}}$ & $0.443 \pm 0.021^{\mathrm{c}}$ & $0.600 \pm 0.050^{\mathrm{a}}$ \\
\hline
\end{tabular}

Different superscripted letters in each column or row indicates significant difference $(P<0.05)$ between the samples.

Table 6: Effect of papaya juice and gelatin level on syneresis of day one yoghurt.

\begin{tabular}{|c|c|c|c|}
\hline \multirow{2}{*}{$\begin{array}{c}\text { Papaya Juice } \\
(\% \mathbf{w} / \mathbf{w})\end{array}$} & \multicolumn{3}{|c|}{ Gelatin Level (\% w/w) } \\
\cline { 2 - 4 } & $\mathbf{0 . 5}$ & $\mathbf{0 . 6}$ & $\mathbf{0 . 7}$ \\
\hline 0 & $17.00 \pm 1.00^{\mathrm{c}}$ & $16.05 \pm 0.95^{\mathrm{bc}}$ & $15.43 \pm 0.07^{\mathrm{bc}}$ \\
\hline 10 & $16.00 \pm 1.00^{\mathrm{bc}}$ & $15.72 \pm 0.25^{\mathrm{bc}}$ & $15.31 \pm 0.30^{\mathrm{b}}$ \\
\hline 15 & $16.00 \pm 1.00^{\mathrm{bc}}$ & $15.57 \pm 0.02^{\mathrm{bc}}$ & $15.30 \pm 0.05^{\mathrm{b}}$ \\
\hline 20 & $16.00 \pm 2.00^{\mathrm{bc}}$ & $15.49 \pm 0.01^{\mathrm{bc}}$ & $15.15 \pm 0.10^{\mathrm{a}}$ \\
\hline
\end{tabular}

Values are mean \pm standard deviation of three replicate samples. Means in a column or row with different superscript letters are different $(p<0.05)$.

\section{Sensory analysis}

Table 5 shows the sensory analysis of the yoghurt samples. Addition of papaya juice significantly $(\mathrm{p}<0.5)$ affected the score of 
yoghurt samples by the consumer panelists for appearance, color, body and texture and overall acceptability (Table 5). Panelists' rating for appearance and color was similar for all yoghurt samples but yoghurt with $10 \%$ papaya juice was rated significantly $(\mathrm{p}<0.5)$ higher than the (control) without papaya juice (Table 6). Addition of up to $15 \%$ papaya juice received significantly higher mean score for overall acceptability, which was in the range of 6.20 to 7.55 (i.e., in the range between like and like very much). However, addition of $20 \%$ papaya juice decreased the ratings to 4.45 to 5.30 , which was between dislike slightly and like slightly.

Yoghurt samples with 10\% papaya juice received higher mean scores for overall acceptance than yoghurt samples with other all papaya juice levels but the difference in mean scores between yoghurt sample without papaya juice (control) was not significant (Table 7). For all sensory attributes, yoghurt samples with $10 \%$ papaya juice had significantly higher mean hedonic scores than the control (without papaya juice), except for appearance in which case both samples received similar scores (Table 7).

Most of the scores given by consumers for appearance, texture, flavor and overall acceptability for each treatment, were concentrated between 5.50 (like slightly) and 7.50 (like very much), on the liked part of the scale for all the treatments.

However, despite the unfamiliarity of the consumers to papaya supplemented yoghurt, participants found the sensory attributes of yoghurt supplemented with papaya juice to be very acceptable. This could be explained by the familiarity of consumers for the individual ingredients, i.e., papaya and milk [43]. In this study, yoghurt containing $10 \%$ papaya juice at all gelatin level had overall acceptability compared to all the other treatments (Table 7).

Table 7: Effect of papaya and gelatin level on consumer acceptability of yoghurt.

\begin{tabular}{|c|c|c|c|c|c|}
\hline \multirow{2}{*}{ Parameters } & \multirow{2}{*}{ Gelatin $(\% \mathrm{w} / \mathrm{v})$} & \multicolumn{4}{|c|}{ Papaya Juice $(\% \mathrm{w} / \mathrm{v})$} \\
\hline & & 0 & 10 & 15 & 20 \\
\hline \multirow{3}{*}{ Body \& Texture } & 0.5 & $6.55 \pm 1.91^{b}$ & $7.6 \pm 1.23^{\mathrm{a}}$ & $7.25 \pm 1.42^{\mathrm{a}}$ & $5.85 \pm 2.50^{c}$ \\
\hline & 0.6 & $6.05 \pm 1.57^{\mathrm{b}}$ & $7.30 \pm 1.08^{\mathrm{a}}$ & $6.40 \pm 1.39^{b}$ & $5.05 \pm 2.61^{c}$ \\
\hline & 0.7 & $6.30 \pm 1.66^{\mathrm{b}}$ & $7.15 \pm 1.14^{\mathrm{a}}$ & $5.90 \pm 1.62^{\mathrm{a}}$ & $5.15 \pm 2.32^{\mathrm{c}}$ \\
\hline \multirow{3}{*}{ Appearance ${ }^{\mathrm{NS}}$} & 0.5 & $5.85 \pm 1.18$ & $6.55 \pm 1.67$ & $6.55 \pm 1.54$ & $6.80 \pm 1.28$ \\
\hline & 0.6 & $5.85 \pm 1.66$ & $6.35 \pm 1.73$ & $6.55 \pm 1.19$ & $6.80 \pm 1.20$ \\
\hline & 0.7 & $5.50 \pm 1.73$ & $6.25 \pm 2.05$ & $6.25 \pm 1.45$ & $6.65 \pm 1.39$ \\
\hline \multirow{3}{*}{ Color $^{\mathrm{NS}}$} & 0.5 & $5.90 \pm 1.55^{c}$ & $6.20 \pm 1.32^{c}$ & $6.10 \pm 1.92^{\mathrm{c}}$ & $6.05 \pm 1.85^{c}$ \\
\hline & 0.6 & $6.90 \pm 1.59^{b}$ & $6.20 \pm 2.24^{c}$ & $7.20 \pm 1.67^{\mathrm{b}}$ & $7.05 \pm 1.46^{b}$ \\
\hline & 0.7 & $6.20 \pm 1.36^{c}$ & $7.15 \pm 1.31^{b}$ & $6.70 \pm 1.17^{c}$ & $6.80 \pm 1.24^{c}$ \\
\hline \multirow{3}{*}{ Flavor } & 0.5 & $6.48 \pm 1.12^{\mathrm{ab}}$ & $6.52 \pm 1.32^{\mathrm{a}}$ & $6.56 \pm 1.27^{a}$ & $6.37 \pm 1.43^{b}$ \\
\hline & 0.6 & $6.37 \pm 1.55^{\mathrm{b}}$ & $6.36 \pm 1.44^{\mathrm{b}}$ & $6.27 \pm 1.28^{\mathrm{b}}$ & $6.17 \pm 1.49^{c}$ \\
\hline & 0.7 & $6.20 \pm 1.18^{\mathrm{bc}}$ & $6.30 \pm 1.05^{b}$ & $6.17 \pm 1.50^{c}$ & $6.12 \pm 2.05^{c}$ \\
\hline \multirow{3}{*}{ Overall acceptability } & 0.5 & $7.00 \pm 1.08^{\mathrm{ab}}$ & $7.55 \pm 0.76^{\mathrm{a}}$ & $7.05 \pm 1.05^{\mathrm{a}}$ & $5.30 \pm 1.75^{c}$ \\
\hline & 0.6 & $6.45 \pm 1.79^{b}$ & $7.50 \pm 1.05^{\mathrm{a}}$ & $7.05 \pm 1.00^{\mathrm{a}}$ & $5.30 \pm 1.66^{c}$ \\
\hline & 0.7 & $6.20 \pm 1.91^{b}$ & $7.35 \pm 0.93^{\mathrm{a}}$ & $6.40 \pm 1.27^{\mathrm{a}}$ & $4.45 \pm 2.01^{\mathrm{d}}$ \\
\hline
\end{tabular}

Values are mean \pm standard deviation of 20 panelist judgments on 9-point hedonic scale. NS=Non-Significant.

\section{Conclusion}

Functional and nutritional values of yogurt and fermented dairy products can be enhanced by adding papaya fruit. In this study, the physicochemical and the majority of the characteristics of yogurts remained unaffected. This value-added functional yogurt appeals to a wide variety of consumers; therefore, it may have the potential to increase sales in the yogurt market. Generally, the results of the current study indicated the possibility of producing papaya juice supplemented yoghurt commercially under small or large-scale condition.

\section{Acknowledgements}

The authors gratefully thank the Functional Food Development Project (NARF) for financial support to carry out the project and Haramaya University and Fedis Agricultural Research Center for technical and material support during sample preparation and identification.

\section{Conflict of interest}

No conflict of interest.

\section{References}

1. Ashenafi M (1994) Fate of Listeria monocytogenes during the souring of 'Ergo' a traditional Ethiopian fermented milk. Journal of Dairy Science 77: 696-702.

2. Gonfa A, Foster HA, Holzapfel WH (2001) Field survey and literature review on traditional fermented milk products of Ethiopia. International Journal of Food Microbiology 68: 173-186.

3. Perdigon G, Moreno De Le Blanc A, Valdez J, Rachid M, Blanc AM (2002) Role of yoghurt in the prevention of colon cancer. European Journal of Clinical Nutrition 56: 565-568.

4. Mahdian E, Tehrani MM (2007) Evaluation of the effect of milk total solids on the relationship between growth and activity of starter cultures and quality of concentrated yoghurt. American-Eurasian journal of Agriculture and Environmental Science 2(5): 587-592.

5. Munzur MM, Islam MN, Akhter S, Islam MR (2004) Effect of different levels of vegetable oil for the manufacture of Dahi from skim milk. AsianAustralean Journal of Animal Science 17: 1019-1025. 
6. Cho E, Seddon JM, Rosner B, Willett WC, Hankinson SE (2004) Prospective study of intake of fruits, vegetables, vitamins, and carotenoids and risk of age-related maculopathy. Archives Ophthalmology 122(6): 883-892.

7. Emun K (2012) Effect of stabilizer and carrot juice on the quality and consumer acceptance of yoghurt (Master of Science Thesis). School of Graduate Studies, Haramaya University, Ethiopia.

8. Fiszman SM, Salvador A (1999) Effect of gelatin on the texture of yoghurt and of acid-heat-induced milk gels. Z Lebensm Unters Forsch, 208: 100105.

9. AOAC (2005) Official method of analysis, 18th edition, association of officiating analytical chemists, Washington DC, USA.

10. Goncalves EM, Pinheiro J, Abreu M, Brandao TRS, Silva CLM (2010) Carrot (Daucus carota L) peroxidase inactivation, phenolic content and physical changes kinetics due to blanching. Journal of food engineering 97(4): 574-581.

11. Hongyu W, Greg JH, John RM (2000) Effects of ultrasound on milk homogenization and fermentation with yogurt starter. Innovative Food Science and Emerging Technologies 1: 211-218.

12. Bandyopadhayay M, Chakraborty R, Raychaudhuri U (2008) Effect of beet and honey on quality improvement and carotene retention in a carrot fortified milk product. Innovative Food Science and Emerging Technologies 9: 9-17.

13. Kiros E, Seifu E, Bultosa G, Solomon WK (2016) Effect of carrot juice and stabilizer on the physicochemical and microbiological properties of yoghurt. LWT - Food Science and Technology 69: 191-196.

14.Villanueva Tiburcio JE, Vargas-Solórzano JW, González Reynoso O, Leandro Laguna C, Alfaro Cruz SC (2016) Effect of ultrasound and thermal treatment on pectin methylesterase activity in papaya (Carica papaya) juice. Journal of Microbiology, Biotechnology and Food Sciences 5(5): 487-490.

15. Greeshma KG, Pushpalatha PB, Sheela KB (2018) Effect of extraction techniques on physicochemical properties of passion fruit juice. International Journal of Applied and Pure Science and Agriculture 4(4): $7-10$

16. Gonfa A, Foster HA, Holzapfel WH (2001) Field survey and literature review on traditional fermented milk products of Ethiopia. International Journal of Food Microbiology 68: 173-186.

17. Krishna KL, Paridhavi M, Patel JA (2008) Review on nutritional, medicinal and pharmacological properties of Papaya (Carica papaya Linn). Nature Product Radiance 7(4): 364-373.

18. Galindo Estrella TS, Herna Ndez Gutie RR, Mateos Di Az J, Sandoval FG, Chel Guerrero L, et al. (2009) Proteolytic activity in enzymatic extracts from Carica papaya L. cv. Maradol harvest by-products. Process Biochemistry 44: 77-82.

19. Kenny 0, O Beirne D (2010) Antioxidant phytochemicals in fresh cut carrot disks as affected by peeling method. Postharvest Biology and Technology 58: 247-253.

20. Bari L, Hassen P, Absar N, Haque ME, Khuda MIIE, et al. (2006) Nutritional analysis of two local varieties of papaya (Carica papaya) at different maturation stages Pakistan Journal of Biological Science 9(1): 137-140.

21. Smolen S, Sady W (2009) The effect of various nitrogen fertilization and foliar nutrition regimes on the concentration of sugars, carotenoids and phenolic compounds in carrot (Daucus carota $L$ ). Sciences of horticulture 120 (3): 315-324.

22. Leja M, Stodolak B, Mareczek A, Wojcicechowska R, Rozek S (1997) Effect of postharvest storage on metabolism of phenol compounds. Folia Horticulture 9(2): 59-69.

23. Kumar P, Mishra HN (2004) Mango soy fortified set yoghurt: effect of stabilizer addition on Physicochemical, sensory and textural properties. Food Chemistry 87: 501-507.

24. Akubor PI (2011) Physicochemical, microbiological and sensory properties of yoghurt supplemented with carrot juice. Nigerian Journal of Nutritional Sciences, 32(1): 15-20.
25. Gonzalez E, Vegara S, Marti N, Valero M, Saura D (2015) Physicochemical characterization of pure persimmon juice: nutritional quality and food acceptability. Journal of Food Science 80(3): C532-C539.

26. Bornare DT, Sumaiya K (2015) Physicochemical and sensory evaluation of [RTS] beverage by incorporating banana pseudostem juice in papaya. International Journal of Engineering Research \& Technology, 4(8): 403408.

27. Rebouças MC, Rodrigues MDCP, Freitas SMD, Ferreira, BBA (2016) The Physicochemical optimization and acceptability of a cashew nut-based beverage varying in mango juice and sugar: A pilot study. Beverages 2(3): 23.

28. Galeboe O, Seifu E, Sekwati Monang B (2018) Production of camel milk yoghurt: Physicochemical and microbiological quality and consumer acceptability. International Journal of Food Studies 7: 51-63.

29. Lim YY, Lim TT, Tee JJ (2007) Antioxidant properties of several tropical fruits: A comparative study. Food Chemistry 103: 1003-1008.

30. Silva CG, Medina NG, Luna NI, Pajilla BL, Saavedra ML (2012) Effect of the proportion of orange (Citrus sinensis), papaya (Carica papaya), and pineapple (Ananas comosus) on sensory acceptability of a mixed nectar. Agroindustrial Science 2(2): 132-138.

31. Shilpi A, Kumar P (2013) Effect of yoghurt cultures and probiotic cultures on physicochemical and sensory properties of mango soy fortified probiotic yoghurt (Msfpy). J Food Process Technol 4(6): 239.

32. Aljerf L, AlMasri N, Prince U (2018) Statistical relationship between milk constituents used in breeding programs during lactation: French case study. International Journal of Case Reports \& Studies 2(2): 90-93.

33. Shikeri AB (2016) Fruit and Vegetables Consumption among Children and Adolescents: Determinants of Consumption and Possible Solutions. Journal of Food Processing and Technology 7(8): 612.

34. Cakmakci S, Tahmas Kahyaoglu D, Erkaya T, Cebi K, Hayaloglu AA (2013) $\beta$-carotene contents and quality properties of set type yoghurt supplemented with carrot juice and sugar. Journal of food processing and preservation 38(2014): 1155-1163.

35. Ramakrishnan U (2002) Prevalence of micronutrient malnutrition worldwide. Nutrition Reviews, 60(5): 46-52.

36. Hickson DW, Dill CW, Morgan RG, Sweat VE, Suter D (1982) Rheological properties of two heat induced protein gels. Journal of Food Science 47: 783-785.

37. Mc Clements DJ, Keogh MK (1995) Physical properties of cold-setting gels formed from heat-denatured whey protein isolate. Journal of the Science of Food and Agriculture 69: 7-14.

38. 0 Kennedy BT, Kelly PM (2000) Evaluation of milk protein interactions during acid gelation using a simulated yoghurt model. Milchwissenschaft 55: $187-190$

39. Oh HE, Wong M, Pinder DN, Hemar Y, Anema SG (2007) Effect of pH adjustment at heating on the rheological properties of acid skim milk gels with added potato starch. International Dairy Journal 17: 13841392.

40. Lucey JA, Munro PA, Singh H (1998) Whey separation in acid skim milk gels made with glucono- $\delta$-lactone: Effects of heat treatment and gelation temperature. Journal of Texture Studies 29: 413-426.

41. Boonrod D, Reanma K, Niamsup H (2006) Extraction and physicochemical characteristics of acid-soluble pectin from raw papaya (Carica papaya) peel. Chiang Mai Journal of Science 33(1): 129-135.

42. Lopes A, Teixeira G, Liberato MC, Pais MS, Clemente A (1998) New vegetal sources for milk clotting enzymes. Journal of Molecular Catalysis B: Enzymatic 5: 63-68.

43. Huotilainen A, Pirttila Backman AM, Tuorila H (2006) How innovativeness related to social representation of new foods and to the willingness to try and use such foods. Food quality and preference 17(5): 353-361. 